\title{
The coastal community perception on the socio-economic impacts of agro-tourism activities in coastal villages in Malaysia
}

\begin{abstract}
This paper is concerned with the socio-economic impacts of agro-tourism activities in coastal villages listed as Desa Wawasan Nelayan (DWN) in Malaysia. The paper discussed the impacts of the two major components of socio-economics dynamics, namely social and economic activities. This account highlights a number of discussions with specific reference to DWN in Malaysia. It identifies the similarities and differences with regard to socioeconomic impact, and it is expected that these points will be of practical use for other agrotourism areas around the globe, and help to increase interest in agro-tourism activities.
\end{abstract}

Keyword: Community development; Agro-tourism; Social development; Economic development; Rural development 